\title{
Pulse polarographic determination of thiophanate methyl fungicide in relation to its soil adsorption study
}

\author{
Devender Kumar Sharma', Naresh K Verma', Sapna Suman ${ }^{1}$ and Rajinder Kumar Kashyap ${ }^{2 *}$
}

\begin{abstract}
Background: The environmental pollution caused by the extensive use of the pesticide thiophanate methyl is of great concern, because it is a category III acute toxicant and a suspected carcinogen.

Method: A remarkably sensitive differential pulse polarographic method for the determination of thiophanate methyl has been developed. The method is based on the reaction of the fungicide with copper(II) perchlorate in the presence of butylmethylimidazolium bromide (ionic liquid) in acetonitrile.

Results: The reaction product exhibits an analytical useful diffusion controlled peak at $-180 \mathrm{mV}$ (vS SCE), and the thiophanate methyl has been determined in the linearity range $1.25 \times 10^{-6}$ to $12.5 \times 10^{-6} \mathrm{~mol} \mathrm{~L}^{-1}$ with a correlation coefficient of 0.997. To study the fate of this pesticide in soil and extent of surface and groundwater contamination, its adsorption on four soils of different soil characteristics has been studied using batch equilibrium technique.

Conclusion: The leaching potential, a measure of ground and surface water contamination, has been evaluated in terms of groundwater ubiquity score (GUS) and the value obtained is in the range 0.87 to 0.97 , classifying it as non-leaching pesticide.
\end{abstract}

Keywords: Thiophanate methyl; Pulse polarography; Copper(II) perchlorate; Soil adsorption study; Leaching potential

\section{Background}

Thiophanate methyl is a bis-thiourea-based systemic fungicide which is extensively used for the control of many fungal diseases in fruits, vegetables, field and plantation crops (Nene and Thapliyal 1979). The environmental pollution caused by the extensive use of this fungicide is of great concern, because it is a category III acute toxicant and a suspected carcinogen (Saquib et al. 2009; Gawande et al. 2010). It also leads to potential toxicological risks to non-target organisms and public health. Concern about the environmental impact of extensive use of pesticides has prompted research into the environmental fate of

\footnotetext{
* Correspondence: rajinder47.rk@gmail.com

${ }^{2}$ Department of Chemistry, Govt. P. G. College, Solan, Himachal Pradesh

173212, India

Full list of author information is available at the end of the article
}

these chemicals which is strongly influenced by their interaction with soil as the latter is the ultimate reservoir for these species irrespective of their application target. In the soil, the pesticides are partitioned between the solution phase and the soil solids through adsorption (Wauchope et. al. 2002). Pesticide adsorption by soil is a naturally occurring phenomenon which influences the extent of surface and groundwater contamination. The presence of pesticides in surface and groundwater has frequently been detected and has led to many workers to carry out experimental study on pesticide adsorption by soils because such studies could provide important information regarding the prediction of pesticide movement in soil and aquifers. 
To accomplish the above objectives, it is, therefore, inevitable to find a simple, sensitive and reliable technique for the analysis of thiophanate methyl. Of the various analytical methods, namely LC (Nakamura et al. 2011), HPLC ( $\mathrm{Li}$ et al. 2013; Ye et al. 2008; Singh et al. 2007) and spectrophotometric (Verma et al. 2004a; Skowron and Ciesielski 2008; Fleeker et al. 1974; Naidu et al. 2011; Mandal et al. 2010; Li and $\mathrm{Li}$ 2007) developed for the determination of thiophanate methyl, very little work has been done on its analysis by polarography (Verma et al. 2004b). The polarographic methods are finding greater use in pesticide analysis, because the determination can be done even at larger dilutions and with smaller volume of solutions without any interference from inert carriers commonly present in formulated products. Differential pulse polarography is well known for its sensitivity and selectivity and has emerged as a reliable, sensitive and cost-effective technique amongst the polarographic methods for analysis. In a significant effort in this context, we have been able to develop a remarkably sensitive method for the determination of thiophanate methyl by making use of its reaction with copper(II) perchlorate in the presence of butylmethylimidazolium bromide (BMIB, an ionic liquid) in acetonitrile. Copper(II) perchlorate in acetonitrile and in the presence of ionic liquid gives a well-defined diffusion controlled peak at $-300 \mathrm{mV}$ (vs SCE), whereas thiophanate methyl gives a similar peak at $180 \mathrm{mV}$. When copper(II) is added to thiophanate methyl in 2:1 molar ratio in the presence of BMIB, both the peaks due to copper(II) and thiophanate methyl disappears completely, and a new peak at $-180 \mathrm{mV}$ appears showing approximately ten times more intensity than the one due to thiophanate methyl alone. The ionic liquid does not show any peak at these potentials and hence does not interfere in the proposed method. The remarkable sensitivity of the new peak coupled with the linear relationship obtained between concentration of thiophanate methyl added to copper(II) and the current intensity of this peak afforded us a sensitive differential pulse polarographic method for the determination of thiophanate methyl. This method has been applied to the analysis of thiophanate methyl in commercial formulation and to study its adsorption on four Indian soils of different soil characteristics. The formulation analysis is not only essential to ensure the quality of the marketed product but also to get reliable adsorption data. The various adsorption parameters, namely soil-adsorption coefficient $\left(K_{d}\right)$, soil organic carbon partition coefficient $\left(K_{\mathrm{oc}}\right)$, Gibb's free energy $\left(\Delta G^{\circ}\right)$ and groundwater ubiquity score (GUS), have been calculated.

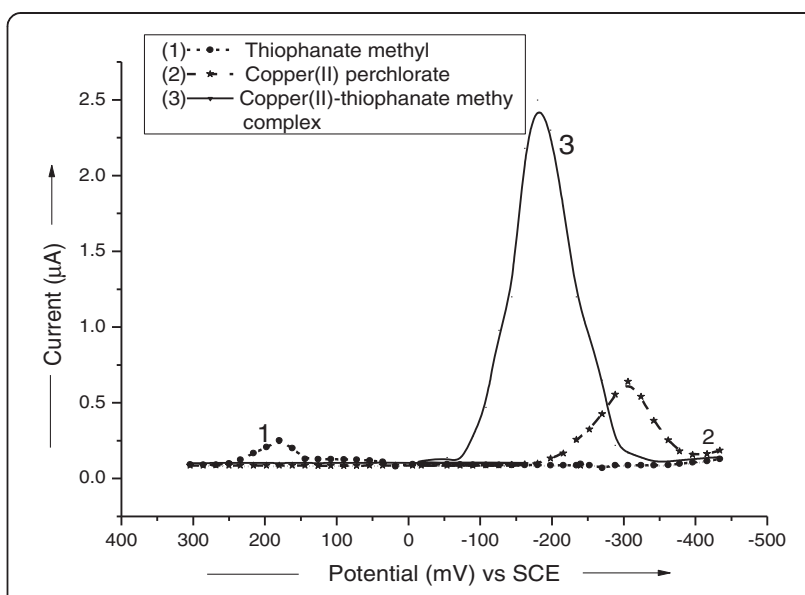

Figure 1 Differential pulse polarograms of thiophanate methyl, copper(II) perchlorate and copper(II)- thiophanate methyl complex. Differential pulse polarograms of thiophanate methyl $\left(10^{-3} \mathrm{~mol} \mathrm{~L}^{-1}\right)$, copper(II) perchlorate $\left(10^{-3} \mathrm{~mol} \mathrm{~L}^{-1}\right)$ and copper(II)-thiophanate

methyl complex (obtained with $10^{-3} \mathrm{~mol} \mathrm{~L}^{-1}$ thiophanate methyl) in the presence of $\mathrm{BMIB}$ in acetonitrile.

\section{Results and discussion}

The use of copper(II) perchlorate in the presence of BMIB in acetonitrile has been described as a voltammetric reagent in developing differential pulse polarographic method for the determination of thiophanate methyl. The polarographic reduction of thiophanate methyl in the presence of above reagent using sodium perchlorate as an electrolyte and Triton-X 100 as suppressor yielded well-defined, diffusion-controlled peak at $-180 \mathrm{mV}$ against SCE electrode showing almost ten times more sensitivity than the one due to thiophanate methyl alone [Figure 1]. The remarkable sensitivity of the new peak coupled with the excellent linear relationship obtained between current intensity of the peak and concentration of thiophanate methyl in the range $1.25 \times 10^{-6}$ to $12.5 \times 10^{-6} \mathrm{~mol} \mathrm{~L}^{-1}$ with a correlation

\begin{tabular}{|c|c|}
\hline Active ingredient taken, $\mu \mathrm{g}$ & Active ingredient found ${ }^{b}, \%$ \\
\hline 0.85 & $98.5 \pm 0.60$ \\
\hline 1.28 & $98.7 \pm 0.84$ \\
\hline 1.71 & $98.2 \pm 0.74$ \\
\hline 2.56 & $98.4 \pm 0.62$ \\
\hline 3.42 & $99.1 \pm 0.76$ \\
\hline
\end{tabular}

${ }^{a}$ Maker's specification established by an independent method (Fleeker et al. 1974). ${ }^{b}$ Mean of three determinations with standard deviation $( \pm)$. 
coefficient of 0.997 has been made the basis of this method. The method has successfully been applied to the analysis of a commercial formulation of thiophanate methyl for its active ingredient content with recoveries in the range $98.2 \%$ to $99.1 \%$ of the nominal content with RSD's in the range $0.60 \%$ to $0.84 \%$ (Table 1). The maker's specification has, however, been established by an independent method (Fleeker et al. 1974). Acetonitrile has been a solvent of choice because of its convenient liquid range, low toxicity, wide electrochemical range, moderate dielectric constant facilitating the solubility of thiophanate methyl and resistance to oxidation or reduction. Further copper(II) perchlorate shows good solution stability in acetonitrile; and in the presence of BMIB ionic liquid, it becomes a powerful oxidant as the resulting copper(I) perchlorate is stabilized by solvation, making it resistant to aerial oxidation. Ionic liquids find wide use in electrochemistry, and their usefulness in accelerating the reaction rate of redox reactions is well known (Welton 2004; Xiaodong et al. 2008; Afsanch et al. 2006; Fabio and Cinzia 2010; Singh et al. 2008). Of the various concentrations of BMIB ionic liquid tested to obtain better results in terms of sensitivity, $0.2 \mathrm{~mL}$ of $2 \times 10^{-4} \mathrm{~mol} \mathrm{~L}-1$ of ionic liquid has been found to be most suitable. Further, BMIB ionic liquid and Triton-X 100 suppressor do not exhibit any peak at $-180 \mathrm{mV}$; hence do not interfere in the method.

The results of analysis indicate that one mole of thiophanate methyl reacts with two moles of copper(II) perchlorate to form most plausibly copper(III)-bis thiourea complex, which generates the new peak at $-180 \mathrm{mV}$ in differential pulse polarography.
The reaction taking place at the mercury electrode is believed to involve the reduction of copper(III)-thiourea complex undergoing one electron change. The same is established by making use of the equation of polarographic wave.

$$
\mathrm{E}=\mathrm{E}_{1 / 2}+0.0591 / \mathrm{n} \log \left[\left(\mathrm{i}_{\mathrm{d}}-\mathrm{i}\right) / \mathrm{i}\right]
$$

Plotting $\left[\log \left(i_{\mathrm{d}}-i\right) / i\right]$ against the corresponding potential $(E)$, a straight line with slope 0.073 is obtained, indicating number of electrons involved to be $0.81(\approx 1)$.

The formation of above copper(III) complex and role of perchlorate ion (a bulky anion) in stabilizing the higher oxidation state of copper(III) complex are quite well known (Victoriano 2002; Golding et al. 1972). The stoichiometry of the fungicide-copper(II) perchlorate reaction has also been established by potentiometric titrations of thiophanate methyl with copper(II) perchlorate in acetonitrile in the presence of BMIB ionic liquid. The titrations have been performed by using platinum electrode as indicator electrode and modified saturated calomel electrode (methanol saturated with KCI used in place of aqueous KCI solution) as reference electrode. In the potentiometric titrations, a sharp rise in potential of the order of $150 \mathrm{mV}$ owing to the oxidation of fungicide was observed at the equivalence point corresponding to fungicide to copper(II) molar ratio of 1:2.

The proposed method has been successfully applied to study the adsorption of thiophanate methyl in soils of different characteristics for the prediction of its movement in soil and aquifer. The adsorption of thiophanate methyl also affects its bioactivity, mobility, persistence and toxicity as these processes are operative only on the unadsorbed fractions of pesticide (Jaya et al. 2009). Consequently, it

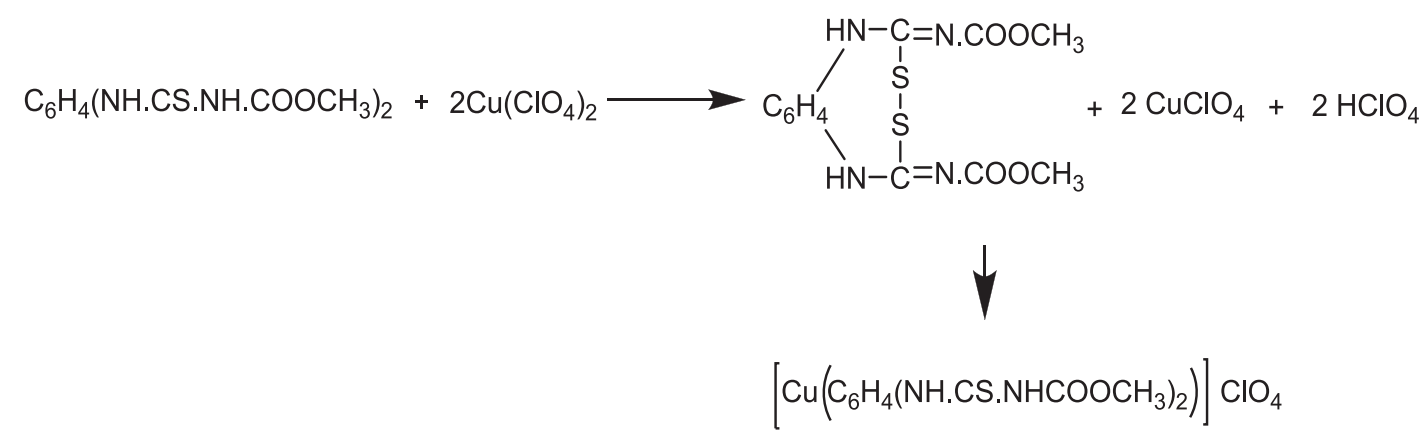

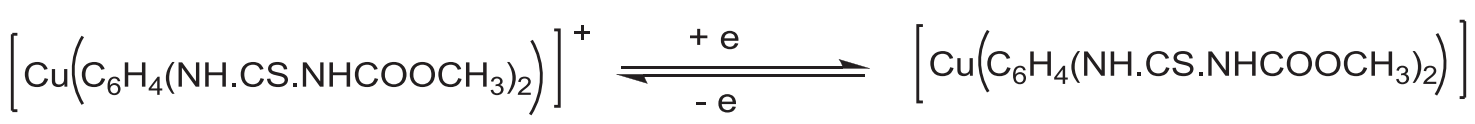


Table 2 Characteristics of the different Indian soils used in the adsorption study of thiophanate methyl

\begin{tabular}{lllll}
\hline Soil sample & $\mathbf{p H}$ & Clay (\%) & $\begin{array}{l}\text { Organic } \\
\text { carbon (\%) }\end{array}$ & $\begin{array}{l}\text { Cation exchange } \\
\text { capacity (meq/100 g) }\end{array}$ \\
\hline I & 7.2 & 32.6 & 0.8 & 13.1 \\
|| & 7.6 & 18.2 & 0.9 & 12.9 \\
III & 6.5 & 20.0 & 1.5 & 11.0 \\
IV & 6.8 & 23.4 & 1.6 & 12.8 \\
\hline
\end{tabular}

influences the extent of surface and groundwater contaminations. Soil characteristics viz. organic mater content, $\mathrm{pH}$ and cation exchange capacity (CEC) modulate the magnitude of pesticide adsorption. Adsorption of pesticide is generally evaluated using adsorption isotherms which represent a functional relationship between the amount of pesticide adsorbed and the pesticide concentration in solution at equilibrium (Somasundaran and Wang 2006; Calvet 1989). The adsorption isotherms of thiophanate methyl on four soils of different characteristics (Table 2) have been evaluated by Freundlich's adsorption equation which is the most widely used in pesticide adsorption study. The adsorption isotherms have been obtained by plotting equilibrium surface excess concentration $\left(C_{s}\right.$ $\mathrm{mg} \mathrm{kg}^{-1}$ ) against the equilibrium solution concentration $\left(C_{e} \mathrm{mg} \mathrm{L}^{-1}\right)$ and are shown in Figure 2. These adsorption isotherms have been classified as L type of Gile's classification (Somasundaran and Wang 2006; Calvet 1989) which represents a system where the solid surface has average affinity for the pesticide and the solvent is relatively inert. In other words, there is no strong competition from solvent for adsorption sites (Fernandez-Perez et al. 2004). The Freundlich's adsorption coefficients $K_{f}$ and $n_{f}$ were calculated from the plot of $\log C_{s}$ vs $\log C_{e}$ (Figure 3),

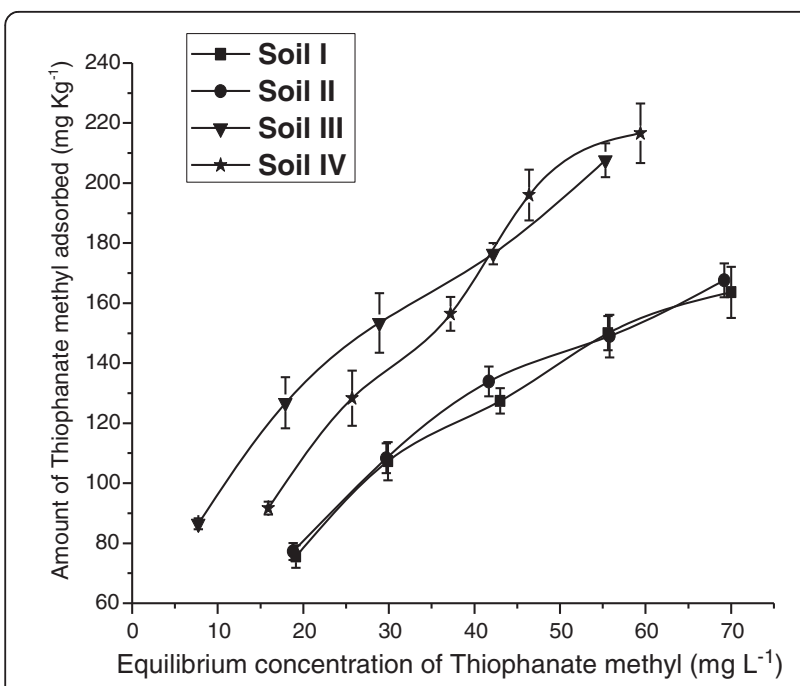

Figure 2 Adsorption isotherm of thiophanate methyl on four different soils.

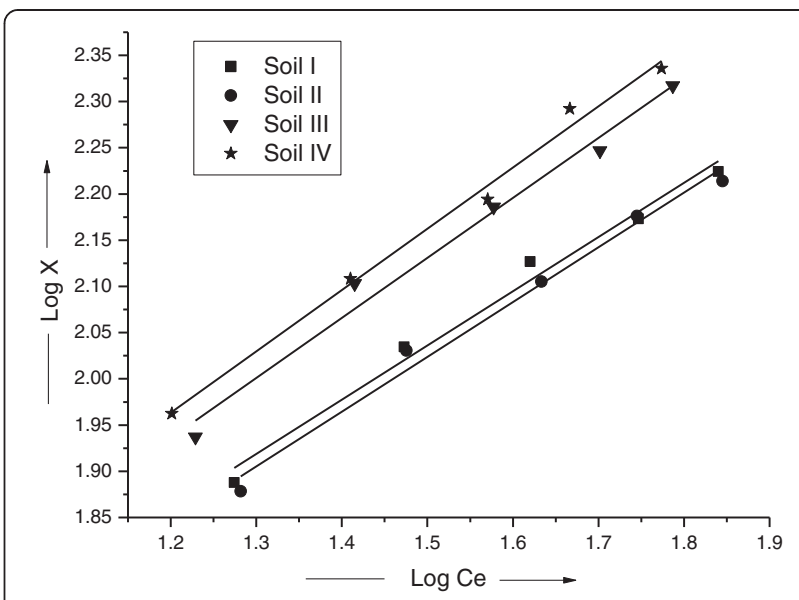

Figure 3 Plot of $\log X$ versus $\log C e$ for the evaluation $K_{f}$ and $n_{f}$. Plot of $\log X$ vs $\log C e$ for the evaluation of Freundlich's adsorption coefficients $K_{f}$ and $n_{f}$ for thiophanate methyl.

and results are summarized in Table 3. The adsorption coefficient $K_{f}$ represents the amount of pesticide adsorbed at an equilibrium concentration of $1 \mathrm{mg} \mathrm{L}^{-1}$, and $n_{f}$ represents the variation in adsorption with varying concentration of pesticide (Jaya et al. 2009). The value of $n_{f}$ for all soil types has been found less than 1 inferring that with increase in the concentration of fungicide, the percentage adsorption by the soil decreases. This might be due to the reason that at higher concentration of the fungicide, there is an increased difficulty to access the adsorption site (Nemeth et al. 2002). The $K_{\mathrm{oc}}$, soil organic carbon partition coefficient has been calculated by normalizing adsorption coefficient $\left(K_{d}\right)$ with the organic carbon (OC) content of the soil. The observed values of $K_{\mathrm{oc}}$ indicate that in soil III and IV, higher adsorption of the fungicide has taken place and this is in conformity with the literature reported values (PRVD 2011). The cation exchange capacity (CEC) relates to the hydrophobic nature of soil, and thiophanate methyl being hydrophobic has higher adsorption affinity in these soils (Pal and Vanjara 2001).

Adsorption of pesticides is less in alkaline than in acidic soils; however, at quite low and high $\mathrm{pH}$, the adsorption decreases due to change in the clay mineralogy (Edwards 1975; Kumar and Philip 2006; Li et al. 2011). Higher adsorption of thiophanate methyl in soils III and

Table 3 Adsorption parameters of thiophanate methyl on four soils at $25 \pm 1^{\circ} \mathrm{C}$

\begin{tabular}{llllllll}
\hline Soil & $\boldsymbol{K}_{\boldsymbol{f}}$ & $\boldsymbol{n}_{\boldsymbol{f}}$ & $\boldsymbol{K}_{\boldsymbol{d}}$ & $\boldsymbol{K}_{\mathrm{OC}}$ & $\log \boldsymbol{K}_{\mathrm{OC}}$ & $\boldsymbol{\Delta} \mathbf{G}^{\mathbf{0}}$ & $\mathrm{GUS}$ \\
\hline I & 14.34 & 0.58 & 3.20 & 401 & 2.60 & -2.890 & 0.87 \\
III & 13.61 & 0.59 & 3.10 & 345 & 2.53 & -2.808 & 0.91 \\
IV & 14.37 & 0.64 & 4.07 & 271 & 2.43 & -3.480 & 0.97 \\
\hline
\end{tabular}


IV are in conformity with the above observations. Further, this fungicide persists longer in acidic soils than in similar soils of alkaline $\mathrm{pH}$ that support the observed behaviour. The negative values of Gibb's free energy $\left(\Delta G^{\circ}\right)$ suggest energetically favourable adsorption process. The leaching potential of thiophanate methyl which is a measure of surface and groundwater contamination has been evaluated in terms of GUS. The GUS values for all soils, ranging from 0.87 to 0.97 , classify it as a non-leacher fungicide and it does not represent a real hazard to groundwater contamination. However, toxicity due to excessive use of this fungicide can be reduced by adjusting the application dose according to soil properties. Further organic amendments such as farmyard manure and compost with higher organic content not only increase the adsorption of this fungicide but also improve the soil fertility and health by serving as the source of soil nutrients.

\section{Methods}

\section{Apparatus}

All polarographic measurements have been made with an Elico (Hyderabad, India) polarographic analyzer (model CL-360). The electrode system consisted of dropping mercury electrode (DME) as a working electrode, saturated calomel electrode (SCE) as a reference electrode and platinum as an auxiliary electrode. Genei shaking incubator (Bangalore, India) has been used in soil adsorption study.

\section{Solvents and reagents}

Acetonitrile (Merck Schuchardt OHG, Germany) was kept over phosphorus pentoxide $\left(5 \mathrm{~g} \mathrm{~L}^{-1}\right)$ and distilled twice. The analytical standard of thiophanate methyl (Sigma-Aldrich Loaborchemikalien $\mathrm{GmbH}$, Munich, Germany) was used, and its stock solution $\left(10^{-4} \mathrm{~mol} \mathrm{~L}^{-1}\right)$ was prepared in acetonitrile. Sodium perchlorate (Merck Schuchardt OHG, Germany) solution $\left(10^{-1} \mathrm{~mol} \mathrm{~L}^{-1}\right.$ in acetonitrile) was prepared by dissolving $12.24 \mathrm{~g}$ of pure compound in $1 \mathrm{~L}$ of acetonitrile. Butylmethylimidazolium bromide (BMIB) (Merck Schuchardt OHG, Germany) solution in acetonitrile $\left(2 \times 10^{-4} \mathrm{~mol} \mathrm{~L}^{-1}\right)$ was used. Copper (II) perchlorate solution in acetonitrile $\left(10^{-3} \mathrm{~mol} \mathrm{~L}^{-1}\right)$ was prepared and standardized as described earlier (Verma and Kumar 1977). Triton-X-100 (Merck Schuchardt OHG, Germany), $0.002 \%$ in acetonitrile was used as suppressor.

\section{Soil samples}

The soils used in the adsorption study were collected from Solan District of Himachal Pradesh, India. The soil samples were air dried, crushed with wooden mortar and sifted through 2-mm sieve. Dried and sieved soil samples were placed in sealed glass jars and stored at room temperature.
Preparation of calibration graph for thiophanate methyl Aliquots $(0.1$ to $3.0 \mathrm{~mL})$ of the stock solution $\left(10^{-4} \mathrm{~mol} \mathrm{~L}^{-1}\right)$ of thiophanate methyl in acetonitrile were taken in polarographic cell mixed with $0.2 \mathrm{~mL}$ of BMIB $\left(2 \times 10^{-4} \mathrm{~mol} \mathrm{~L}^{-1}\right.$ in acetonitrile), $4.0 \mathrm{~mL}$ of copper(II) perchlorate $\left(10^{-3} \mathrm{~mol} \mathrm{~L}^{-1}\right.$ in acetonitrile) and Triton-X-100 $(2 \mathrm{~mL}, 0.002 \%$ in acetonitrile), and final volume was made to $20 \mathrm{~mL}$ with sodium perchlorate $\left(10^{-1} \mathrm{~mol} \mathrm{~L}^{-1}\right.$ in acetonitrile). Nitrogen gas was bubbled through each solution for $5 \mathrm{~min}$. The differential pulse polarogram of each solution was recorded at room temperature $(25 \pm 1)^{\circ} \mathrm{C}$ with the following instrumental parameters: initial potential $=400 \mathrm{mV}$; drop time $=1 \mathrm{~s}$; pulse amplitude $=50 \mathrm{mV}$; and scan rate $=$ $6 \mathrm{mV} \mathrm{s}^{-1}$. A calibration graph was constructed by plotting peak current $(\mu \mathrm{A})$ (corresponding to $-180 \mathrm{mV}$ peak) vs concentration of thiophanate methyl $\left(\mathrm{mol} \mathrm{L}^{-1}\right)$. The linear relationship between the concentration of the fungicide and the peak current is obeyed in the range $1.25 \times 10^{-6}$ to $12.5 \times 10^{-6} \mathrm{~mol} \mathrm{~L}^{-1}$. The linear regression equation has the value of slope and intercept as 0.02693 and 0.01204 with a correlation coefficient 0.997 .

\section{Formulation analysis}

A wettable powder formulation, Hexatop-70, containing $70 \%$ active ingredient, procured from the authorized pesticide dealer, was used. A sample of formulation equivalent to 3.42 - $\mathrm{mg}$ active ingredient was dissolved in $10 \mathrm{~mL}$ acetonitrile. The solution was further diluted to $100 \mathrm{~mL}$ with the same solvent and aliquots $(0.5$ to $2.0 \mathrm{~mL})$ of this solution were taken and processed for analysis as described above for the pure compound. Assay results are given in Table 1.

\section{Soil adsorption study}

Thiophanate methyl adsorption isotherm on four Indian soils of different soil characteristics (Table 2) were obtained by the batch equilibration technique using $50-\mathrm{mL}$ conical flask (Celis et al. 2005). Triplicate soil samples $(2 \mathrm{~g})$ were equilibrated with thiophanate methyl solutions in the concentration range from 34.24 to $102.72 \mu \mathrm{g} \mathrm{mL}$ on shaker at $150 \mathrm{rpm}$ at room temperature $(25 \pm 1)^{\circ} \mathrm{C}$ for $24 \mathrm{~h}$ of equilibrium time (estimated time required for equilibrium to be reached between fungicide adsorbed and in solution). After equilibration, the suspensions were centrifuged and the equilibrium concentrations $\left(C_{e}\right)$ were determined in supernatants by the proposed method described above. Adsorption isotherms were evaluated by using Freundlich's adsorption equation:

$$
X=K_{f} C_{e}^{n_{f}}
$$

Where $X$ is the amount of pesticide adsorbed $\mathrm{mg} \mathrm{kg}^{-1}$ of the adsorbent; $C_{e}$ is the equilibrium concentration in solution $\left(\mathrm{mg} \mathrm{L} \mathrm{L}^{-1}\right)$; and $K_{f}$ and $n_{f}$ are adsorption 
coefficients that characterize the adsorption capacity of the adsorbent. The adsorption coefficients $K_{f}$ and $n_{f}$ are calculated from the least square methods applied to the linear form of the Freundlich's adsorption equation (Figure 3).

$$
\log X=\log K_{f}+n_{f} \log C_{e}
$$

Other adsorption parameters for adsorption process, namely, soil-adsorption coefficient $\left(K_{d}\right)$, soil organic carbon partition coefficient $\left(K_{\text {oc }}\right)$, Gibb's free energy $\left(\Delta G^{\circ}\right)$ and groundwater ubiquity score (GUS) have been calculated by using the following equations (Vischetti et al. 2002; Papa et al. 2004; Bhardwaj et al. 2007).

$$
\begin{aligned}
& K_{d}=\frac{X}{C_{e}} \\
& \Delta G^{\circ}=-R T \ln K_{d} \\
& K_{o c}=K_{d} \times\left(\frac{100}{\% \text { O.C. }}\right)
\end{aligned}
$$

Where $R=$ gas constant, $T=$ absolute temperature, $t_{1 / 2}=$ pesticide persistence (half-life), $\mathrm{OC}=$ organic carbon content of soil. All adsorption parameters for the adsorption of thiophanate methyl have been calculated and are given in Table 3.

\section{Evaluation of leaching behaviour of thiophanate methyl} A number of models are available to evaluate the leaching behaviour of pesticides and associated environmental pollution risks. In the present study, leaching potential of these pesticides has been evaluated in terms of groundwater ubiquity score (GUS) which is the most commonly used model and it relates pesticide persistence (half-life) and adsorption in soil $\left(K_{\mathrm{oc}}\right)$. The leaching potential of thiophanate methyl in terms of GUS index has been determined by using experimentally observed $K_{\mathrm{oc}}$ value for each soil sample and literature reported half-life of thiophanate methyl (PRVD 2011).

$$
\text { GUS }=\log t_{1 / 2}\left[4-\log \left(K_{o c}\right)\right]
$$

GUS value is used to study the leaching behaviour of pesticides, classifying them as leacher (GUS > 2.8); non-leacher $(\mathrm{GUS}<1.8)$ and transition $(2.8>\mathrm{GUS}<1.8)$ (Gustafson 1989).

\section{Conclusion}

The proposed pulse polarographic method for the determination of thiophanate methyl is simple, sensitive and reliable, and the determination of the fungicide can be done at larger dilution with smaller volume of sample solution without any interference from inert carrier present in formulations. From the soil adsorption study, the values of $K_{\mathrm{oc}}$ suggest greater adsorption in soil types and consequently inhibit the penetration of fungicide into water sources. The GUS value is far below than 1.8 classifying it as a non-leacher and does not represent a real hazard to groundwater contamination.

\section{Competing interests}

The authors declare that there are no competing interests.

\section{Authors' contributions}

DSK and RK conceived of the original idea and design of the work. RK, NKS and AG performed the collection of soil samples, preparation of reagents and solutions and execution of experiments. DKS and RK performed the data interpretation and manuscript writing. All authors read and approved the final manuscript.

\section{Author details}

${ }^{1}$ Department of Chemistry, Himachal Pradesh University, Shimla 171005 Himachal Pradesh, India. 'Department of Chemistry, Govt. P. G. College, Solan, Himachal Pradesh 173212, India.

Received: 9 February 2014 Accepted: 27 January 2015

Published online: 03 April 2015

\section{References}

Afsanch S, Zarangi M, Daryush M, Noronz M (2006) Dramatic effects of ionic liquid on platinum electrode surface and electron-transfer rates of mesotetraphenylporphyrins. Electroanalysis 18:1227-1229

Bhardwaj D, Sharma P, Tomar R (2007) Restriction of pesticidal movement in contaminated soil and water. Indian J Chem Sect A 46:1796-1800

Calvet R (1989) Adsorption of organic chemicals in soils. Environ Health Prosp 83:145-177

Celis R, Facenda G, Hermosin MC, Cornejo J (2005) Assessing factors influencing the release of hexazinone from clay-based formulations. Int J Environ Anal Chem 85:1153-1164

Edwards CA (1975) Factors that affect the persistence of pesticides in plants and soils. Pure and Appllied Chem 42:39-56

Fabio B, Cinzia C (2010) The heck reaction in ionic liquids: progress and challenges. Molecules 15:2211-2245

Fernandez-Perez M, Flores-Cespedes F, Gonzalez-Paradas E, Villafranca-Sánchez M, Perez- Garacia S, Garrido-Herrera FJ (2004) Use of activated bentonites in controlled release formulations of atrazine. J Agri Food Chem 52:3888-3893

Fleeker JR, Lacy NM, Schultz IR, Houkom EC (1974) Persistence and metabolism of thiophanate - methyl in soil. J Agric Food Chem 22:592-595

Gawande MR, Murli N, Binjhade A, Shrivastava VK (2010) Carbendazim induced histopathological changes in adrenal, thyroid glands and some enzyme activities in adrenal gland of Rattus rattus. Int J Bio Technol 1(2):38-43

Golding RM, Harris CM, Jessop KJ, Tennnat WC (1972) Oxidation of dithiocarbamato metal complexes. Aust J Chem 25:2567-2676

Gustafson DI (1989) Groundwater ubiquity score - a simple method for assessing pesticide leachability. Environ Toxicol Chem 8:339-357

Jaya M, Singh SB, Kulshrestha G, Arya S (2009) Adsorption behaviour of alachlor on soil, FYM and charcoal. Pest Res J 21:101-104

Kumar M, Philip L (2006) Adsorption and desorption characteristics of hydrophobic pesticide endosulfan in four Indian soils. Chemosphere 62:1064-1077

Li P, Liu KL, Yang X, Zhao YF, Yong N (2013) Determination of carbendazim and thiophanate-methyl in red wine by high pressure liquid chromatography-linear ion trap mass spectrometry. J Food Safety Quality 4(1):89-93

Li Q, Li WX (2007) Determination of methyl thiophanate and carbendazim in fruits with ultraviolet spectrometer. Deciduous Fruits 3:47-48

Li X, Zhou Q, Wei S, Ren W, Sun X (2011) Adsorption and desorption of carbendazim and cadmium in typical soils in north-eastern China as affected by temperature. Geoderma 160:347-354

Mandal S, Das S, Bhattacharyya A (2010) Dissipation study of thiophanate methyl residue in/on grapes (Vitis vinifera L.) in India. Bull Environ Contam Toxicol 84:592-595

Naidu PK, Niranjan T, Naidu VSN (2011) Spectrophotometric determination of carbendazim in its formulations and environmental samples. Int J Chem Tech Research 3(4):1728-1733

Nakamura M, Furumi Y, Watanabe F, Nizukoshi K, Taniguchi M, Nemoto S (2011) Determination of carbendazim, thiophanate, thiophanate-methyl and benomyl 
residues in agricultural products by liquid chromatography-tandem mass spectrometry. Food Hyg Saf Sci 52(3):148-153

Nemeth KL, Fuleky G, Maroyan G, Csokan P (2002) Sorption behaviour of acetochlor, atrazine, carbendazim, diazinon, imidacloprid and isoproturon on Hungarian agricultural soil. Chemesphere 48:545-552

Nene YL, Thapliyal PN (1979) Fungicides in plant disease control, 2nd edn. Oxford and IBH Pub. Co., New Delhi, India, 248

Pal OR, Vanjara AK (2001) Removal of malathion and butachlor from aqueous solution by clays and organoclays. Sep Purif Technol 24:167-172

Papa E, Castiglioni S, Gramatica P, Nikolayenko V, Kayumov O, Calamari D (2004) Screening the leaching tendency of pesticides applied in the Amu Darya Basin (Uzbekistan). Water Res 38:3485-3494

Proposed Re-evaluation Decision PRVD (2011) Pest management regulatory agency, health Canada

Saquib Q, Al-Khedhairy AA, Al-Arifi S, Dhawan A, Mussart J (2009) Assessment of methyl thiophanate-Cu (II) induced DNA damage in human lymphocytes. Toxicol In Vitro 23:848-854

Singh SB, Foster GD, Khan SU (2007) Determination of thiophanate methyl and carbendazim residues in vegetable samples using microwave-assisted extraction. J Chromatogr A 1148:152-157

Singh R, Sharma M, Mangain R, Rawat DS (2008) Ionic liquids: a versatile medium for palladium-catalyzed reactions. J Braz Chem Soc 19:357-379

Skowron M, Ciesielski W (2008) Determination of thiophanate methyl using iodine-azide reaction. Chem Anal (Warsaw) 53:133-139

Somasundaran P, Wang D (2006) Mineral-flotation reagent equilibria, in solution chemistry: minerals and reagents, ed. B.A. Wills. Elsevier, The Netherlands, p 73

Verma BC, Chauhan C, Thakur L, Sharma DK (2004a) Determination of thiophanate methyl in its formulation and agricultural produce by differential pulse polarography. Pest Res I 16:90-93

Verma BC, Kumar S (1977) Non-aqueous redox determination of ascorbic acid with copper(II). Talanta 24:694-695

Verma BC, Sood S, Chauhan C, Sharma DK (2004b) A simple and rapid spectrophotometric method for determination of thiophanate-methyl in commercial formulations and its residues in foodstuffs. J AOAC Int 87(4):811-814

Victoriano LI (2002) Copper(III) dithiocarbamates - an undergraduate experimental project with unexpected challenges. J Chem Educ 79(10):1252

Vischetti C, Marcuchini C, Leita L, Cantone P, Danuso F, Giovanardi R (2002) Behaviour of two sunflower herbicides (metobromuron, aclonifen) in soil. Eur J Agron 16:231-238

Wauchope RD, Yeh S, Linders JBHJ, Kloskowski R, Tanaka K, Rubin B, Katayama A, Kördel W, Gerstl Z, Lane M, Unsworth J (2002) Review. Pesticides soil sorption parameters: theory, measurement, uses, limitations and reliability. Pest Manag Sci 58:419-445

Welton T (2004) Ionic liquids in catalysis. Coord Chem Rev 248:2459-2477

Xiaodong SG, Zhang H, Zheng J (2008) Electrochemical behaviour and differential pulse voltammetric determination of paracetamol at a carbon ionic liquid electrode. Anal Bioanal Chem 391:1049-1055

Ye C, Zhou Q, Wand X (2008) Determination of thiophanate-methyl and chlorotoluron in water samples by improved single-drop microextraction coupled with high-performance liquid chromatography. Int J Environ Anal Chem 88(7):461-471

\section{Submit your manuscript to a SpringerOpen ${ }^{\circ}$ journal and benefit from:}

- Convenient online submission

- Rigorous peer review

- Immediate publication on acceptance

- Open access: articles freely available online

- High visibility within the field

- Retaining the copyright to your article

Submit your next manuscript at $\gg$ springeropen.com 